\title{
Structural Homology of Human, Bovine, and Porcine Milk Lactoferrins: Evidence for Shared Antigenic Determinants
}

\author{
J. SCOTT MAGNUSON, JOSEPH F. HENRY, TAI-TUNG YIP, AND T. WILLIAM HUTCHENS \\ USDA/ARS Children's Nutrition Research Center, Department of Pediatrics, Baylor College of Medicine and \\ Texas Children's Hospital, Houston, Texas 77030
}

\begin{abstract}
Although some degree of structural homology has been demonstrated among lactoferrins of different species, other reports suggest that these proteins are immunologically distinct. Human, bovine, and porcine lactoferrins were purified to homogeneity from colostral whey by affinity chromatography on immobilized single-stranded DNA. Evidence for shared antigenic determinants among human, bovine, and porcine lactoferrins was demonstrated by Ouchterlony immunodiffusion and immuno "dot" blots using whole antisera and purified Ig directed against each species of lactoferrin. There was no evidence that human transferrin was recognized by any of the lactoferrin-specific antisera evaluated. The degree of cross-reactivity between the lactoferrins and their trypsin digestion products was also evaluated after SDS-PAGE by immunoblotting. These data demonstrate that human, porcine, and bovine lactoferrins share common antigenic determinants and are likely to be more homologous in tertiary structures than suggested previously. Thus, investigations of human or bovine lactoferrin metabolism in infants that are based upon immunologic methods alone should be conducted cautiously in those cases where the presence of both human and bovine lactoferrin is suspected. (Pediatr Res 28: 176-181, 1990)
\end{abstract}

\section{Abbreviations}

HEPES, $N$-2-hydroxyethylpiperazine- $N^{\prime}$-2-ethanesulfonic acid

Lactoferrin is a $78-\mathrm{kDa}$ metal-binding glycoprotein that belongs to the transferrin gene family (1). Similar to the serum iron transport protein, transferrin, lactoferrin contains one high-affinity metal-binding site in each of its two similar lobes. In the case of iron binding, the two high-affinity sites use identical residues as ligands to sequester iron in the presence of bicarbonate ions (2). These sites, as well as additional surface metal binding sites, may also be occupied with several other metal ions (3).

Human milk lactoferrin has been characterized more fully than any other lactoferrin. Its amino acid sequence (4) and tertiary structure (2) are known. Amino acid and cDNA sequence data indicate that several animal lactoferrins share extensive

Received February 5. 1990: accepted April 3, 1990.

Correspondence and reprint requests: T William Hutchens, Department of Pediatrics (CNRC), Baylor College of Medicine, 1100 Bates, Houston, TX 77030.

Funded, in part, with federal funds from the U.S. Department of Agriculture, Agricultural Research Service under Cooperative Agreement number 58-7MN1-6 100. The contents of this publication do not necessarily reflect the views or policies of the U.S. Department of Agriculture, nor does mention of trade names, commercial products, or organizations imply endorsement by the U.S Government. regions of primary sequence homology. Specifically, $N$-terminal sequence information for porcine lactoferrin (5) indicates homology between human (4), bovine (6), equine (7), monkey (8), and murine (9) lactoferrins. Peptide mapping also has been used to suggest structural homology between porcine and human lactoferrins (10). The preliminary structure (x-ray diffraction) for bovine lactoferrin (11) also demonstrates some degree of structural homology between human and bovine lactoferrins.

Although members of the transferrin gene family may be viewed as similar in function and overall structure, considerable differences exist in the surface structure of these proteins (12). Specifically, the question of common antigenicity among the milk lactoferrins has not been fully characterized and there is some disagreement on species cross-reactivity. Masson and Heremans (13) used immunodiffusion and reported some cross-reactivity between human and porcine lactoferrin, but Kokriakov et al. (10) reported no cross-reactivity between the two species. Wang et al. (6) reported the absence of cross-reactivity between human and bovine lactoferrin based on immunodiffusion. Davidson and Lonnerdal (8) also used immunodiffusion to report cross-reactivity between monkey and human lactoferrin, but did not detect cross-reactivity between human and bovine lactoferrins. Rotova et al. (14) also reported no cross-reactivity between porcine and bovine lactoferrins on the basis of their immunodiffusion studies.

We have recently reported the use of immobilized DNA for the rapid purification of human and porcine lactoferrins $(5,15)$. This technique has also been used by us to purify bovine lactoferrin (Hutchens TW, Magnuson JS, Yip T-T, unpublished data). We applied the purified lactoferrins in investigations of possible structural homologies in which we used more sensitive immunologic methods than have been used previously to address this question. In this report, we demonstrate evidence for common antigenic determinants on human, porcine, and bovine lactoferrins.

\section{MATERIALS AND METHODS}

Porcine colostrum was obtained from Dr. Darrell A. Knabe Department of Animal Science, Texas A \& M University. Bovine colostrum was generously donated by Elmer Beckendorf of E. L Beckendorf and Sons, Tomball, Texas. Human colostrum was provided by the Children's Nutrition Research Center Humar Milk Bank, Department of Pediatrics, Baylor College of Medi cine, Houston, Texas. The colostrum from each species wa collected on d 1 postpartum and stored at -20 or $-80^{\circ} \mathrm{C}$ unti use.

Whey preparation. Frozen porcine and bovine colostrum wa thawed at $37^{\circ} \mathrm{C}$, and centrifuged at $12000 \times g$ for $30 \mathrm{~min}$ at $4^{\circ} \mathrm{C}$ The lipid layer was removed and the skim milk proteins de canted. Casein was removed by rennin (Sigma Chemical Co., St Louis, MO) precipitation at $34^{\circ} \mathrm{C}$ and centrifugation at $12000 \times$ 
$g$ for $30 \mathrm{~min}$ at $4^{\circ} \mathrm{C}$. Human colostrum was thawed at $37^{\circ} \mathrm{C}$ and the $\mathrm{pH}$ adjusted to 4.3 . The low $\mathrm{pH}$ colostrum was stirred for 1 $\mathrm{h}$ at $4^{\circ} \mathrm{C}$, then centrifuged at $45000 \mathrm{rpm}$ in a Beckman TY45 Ti rotor for $45 \mathrm{~min}$ at $4^{\circ} \mathrm{C}$. The lipid layer was removed and the whey decanted.

Affinity chromatography on single-stranded DNA-agarose. Single-stranded DNA-agarose (lot no. 8NW301; $1.0 \mathrm{mg} \mathrm{DNA} / \mathrm{mL}$ gel) was obtained from Bethesda Research Laboratory (Bethesda, MD) and packed into a $2.5-\mathrm{cm}$ inner diameter column to a bed volume of 80 to $100 \mathrm{~mL}$. The column was washed with water, then equilibrated with $20 \mathrm{mM}$ HEPES buffer ( $\mathrm{pH} 8.0$ ) containing $6 \mathrm{M}$ urea, at a flow rate of $30 \mathrm{~mL} / \mathrm{h}$. The separation procedure was performed at room temperature $\left(20\right.$ to $25^{\circ} \mathrm{C}$ ). Solid urea (to $6 \mathrm{M}$ ) was added to the sample before it was applied to the DNA affinity column. The columns were washed $(10 \times$ bed volume $)$ with column equilibration buffer. Before gradient elution, the urea was removed with 5-10 column volumes of $20 \mathrm{mM}$ HEPES buffer ( $\mathrm{pH} 8.0)$. Lactoferrin was eluted with stepwise increments of $\mathrm{NaCl}(0.2$ and $0.5 \mathrm{M})$ in $20 \mathrm{mM}$ HEPES $\mathrm{pH} 8.0$ buffer. Absorbance at $280 \mathrm{~nm}$ was measured in each of the collected fractions. After each purification procedure, the DNA-agarose column was washed extensively, first with $2 \mathrm{M} \mathrm{NaCl}$ in $20 \mathrm{mM}$

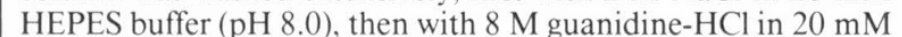

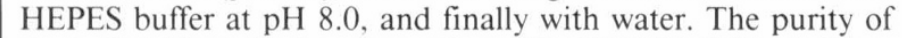
the isolated lactoferrins was evaluated by SDS-PAGE and silverstaining, high-performance reverse-phase (phenyl) chromatography, high-performance ion-exchange (Mono-S) chromatography, and $N$-terminal amino acid sequence analyses $(5,15,16)$.

Preparation of antisera and purified Ig specific for lactoferrin. Commercial antibodies against human lactoferrin were obtained from Dako Corporation (Carpinteria, CA) and Cappel (West Chester, PA). Additional antisera against our purified preparations of human, porcine, and bovine lactoferrin were prepared in New Zealand White rabbits by multiple injections (5) of lactoferrin over a 3-mo period, each in Freund's complete adjuvant (Bethyl Laboratories, Montgomery, TX). The antibodies were purified by thiophilic adsorption (17-19) or by diethylaminoethyl-cellulose chromatography (20) as indicated.

Ouchterlony immunodiffusion. Immunologic tests of identity were performed using Ouchterlony's comparative double-diffusion system (21). Six wells, $4 \mathrm{~mm}$ in diameter spaced 3 or $6 \mathrm{~mm}$ apart, were placed radially around a central well. The gel was composed of $0.9 \%$ agarose (Sea Kem, FMC Corporation, Rockland, ME) in PBS, $\mathrm{pH}$ 7.4. Twenty $\mu \mathrm{L}$ of various antigen and antibody solutions were applied to the wells as indicated. The purified antibodies used were rabbit antihuman lactoferrin, rabbit antibovine lactoferrin, and rabbit antiporcine lactoferrin (described above). The absorbance $(280 \mathrm{~nm})$ of the purified antibodies ranged from 20 to 80 . Human lactoferrin standard was obtained from Jackson ImmunoResearch Laboratories, West Grove, PA. Bovine lactoferrin standard was obtained from Sigma. Human serum transferrin was included as a control (Sigma). The absorbance $(280 \mathrm{~nm})$ of the antigens ranged from $0.4-5.0$.

Antibody was placed into the central well and antigen was placed into the radial wells. The concentration of the homologous lactoferrin to which the antisera was raised was one tenth that of the heterologous lactoferrins or human transferrin. The agarose gels were placed into a humidified chamber at $4^{\circ} \mathrm{C}$ overnight to allow diffusion. Direct photoreproductions of the gels (with gel placed in the enlarger) were taken after the immunodiffusion gels were soaked overnight in PBS $(100 \mathrm{~mL})$. The immunodiffusion gels were oven dried $\left(60^{\circ} \mathrm{C}\right.$ for 2 to $\left.6 \mathrm{~h}\right)$ before staining $(0.125 \%$ Coomassie Brilliant Blue G250 in $10 \%$ acetic acid, $50 \%$ methanol, and $40 \%$ water). Gels were destained ( $10 \%$ acetic acid, $50 \%$ methanol, $40 \%$ water) at room temperature until a clear background was evident.

Immuno "dot" blot analyses. Immuno dot blots were performed using a microfiltration Bio-Dot apparatus and procedures provided by Bio-Rad (Richmond, CA). Nitrocellulose mem- branes (Bio-Rad) were used to bind the antigen or control protein of interest $(0.015$ to $300 \mu \mathrm{g})$ and then were blocked with either $1 \%$ (wt/vol) BSA (World Health Organization) or $0.1 \%$ (wt/vol) horse skeletal muscle myoglobin (Sigma). After exposing antigen with primary antibody (whole antiserum diluted 1:10 or purified antibodies at $\sim 1 \mathrm{mg} / \mathrm{mL}$ ), a horseradish peroxidase-conjugated secondary antibody (goat antirabbit IgG against heavy and light chain, Bio-Rad) was incubated with the membrane according to the manufacturer's instructions. Color development was initiated by adding 4-chloro-1-napthol with hydrogen peroxide in methanol.

Electrophoretic (Western) transfer and immunoblotting. SDSPAGE (10-20\% total acrylamide, 3\% percent of acrylamide represented by bis-acrylamide) was performed under denaturing conditions as described previously $(15,16)$, except that reducing agents were eliminated during sample preparation. Approximately $5 \mu \mathrm{g}$ protein were loaded into each well of the gel. Western transfer was performed on nitrocellulose membranes (Bio-Rad) at $\mathrm{pH} 8.3$ in $0.025 \mathrm{M}$ Tris, $0.19 \mathrm{M}$ glycine, $20 \%$ methanol buffer at $30 \mathrm{~V}$ for $16 \mathrm{~h}$ at room temperature $\left(22-25^{\circ} \mathrm{C}\right)$. After $16 \mathrm{~h}$, the voltage was increased to $60 \mathrm{~V}$ for $1 \mathrm{~h}$. The nitrocellulose membranes were blocked for $1.5 \mathrm{~h}$ at $37^{\circ} \mathrm{C}$ with $0.1 \%$ myoglobin (horse skeletal muscle, Sigma) in $5 \mathrm{mM}$ Tris- $\mathrm{HCl}, 0.15 \mathrm{M}$ sodium chloride, $\mathrm{pH}$ 8.0. After blocking, the membrane was incubated for $1.5 \mathrm{~h}$ at $37^{\circ} \mathrm{C}$ with either rabbit antihuman, rabbit antiporcine, or rabbit antibovine lactoferrin primary antibodies (purified $\mathrm{Ig}$ fraction) diluted in $5 \mathrm{mM}$ Tris- $\mathrm{HCl}(\mathrm{pH} 8.0), 0.15 \mathrm{M} \mathrm{NaCl}$, and $0.05 \%$ Tween-20. After incubation with the primary antibody, the membrane was incubated for $1.5 \mathrm{~h}$ at $37^{\circ} \mathrm{C}$ with diluted goat antirabbit $\mathrm{IgG}$ antibodies conjugated with horseradish peroxidase (Bio-Rad). Color was developed using 4-chloro-1-napthol with hydrogen peroxide in methanol.

Trypsin digestion of human, bovine, and porcine lactoferrins. Diferric human lactoferrin (Jackson ImmunoResearch), bovine lactoferrin (Morinaga Milk Industry Co., Zama City, Kanagawa, Japan $)$, and purified porcine lactoferrins $(10 \mathrm{mg} / \mathrm{mL})$ were subjected to mild trypsin digestion in $0.1 \mathrm{M}$ Tris- $\mathrm{HCl}(\mathrm{pH} 8.2)$ with $0.025 \mathrm{M}$ calcium chloride containing bovine pancreas trypsin (Boehringer Mannheim, Indianapolis, IN) at an enzyme/substrate ratio of $1: 50$. The mixture was incubated at $37^{\circ} \mathrm{C}$ for 3.5 $\mathrm{h}$, then inactivated with soybean trypsin inhibitor (Sigma). Lactoferrin digestions were monitored by SDS-PAGE and highperformance reverse-phase (phenyl) chromatography as described elsewhere (5).

\section{RESULTS}

The possibility of shared antigenic determinants among the purified human, bovine, and porcine lactoferrins was investigated first by Ouchterlony immunodiffusion, then by the more sensitive immuno dot blot method, and by Western transfer of SDS-polyacrylamide gels obtained after electrophoresis of both intact and trypsin-digested lactoferrins.

Direct visual evidence (unstained gels) for precipitation during Ouchterlony immunodiffusion of unfractionated antisera against the different species of lactoferrin was weak, but clear (data not shown). If the antisera were concentrated ( 3 to 5 times) or if the antibodies were first purified, precipitin lines generated by Ouchterlony immunodiffusion were stronger. The results shown in Figures 1 to 3 demonstrate the type of evidence obtained by Ouchterlony immunodiffusion using antibodies purified by diethylaminoethyl-cellulose chromatography (20). Similar results were obtained with antibodies purified by thiophilic adsorption (17-19) (data not shown). Although the homologous antigenantibody reactions were most obvious, preciptin bands could be observed for every combination of lactoferrin and antilactoferrin antibody evaluated (regardless of source). Using the range of antibody and antigen concentrations specified, precipitin lines were detected using wells that were either $3 \mathrm{~mm}$ (Figs. 1-3) or 6 $\mathrm{mm}$ apart (not shown). For each of the different antilactoferrin 


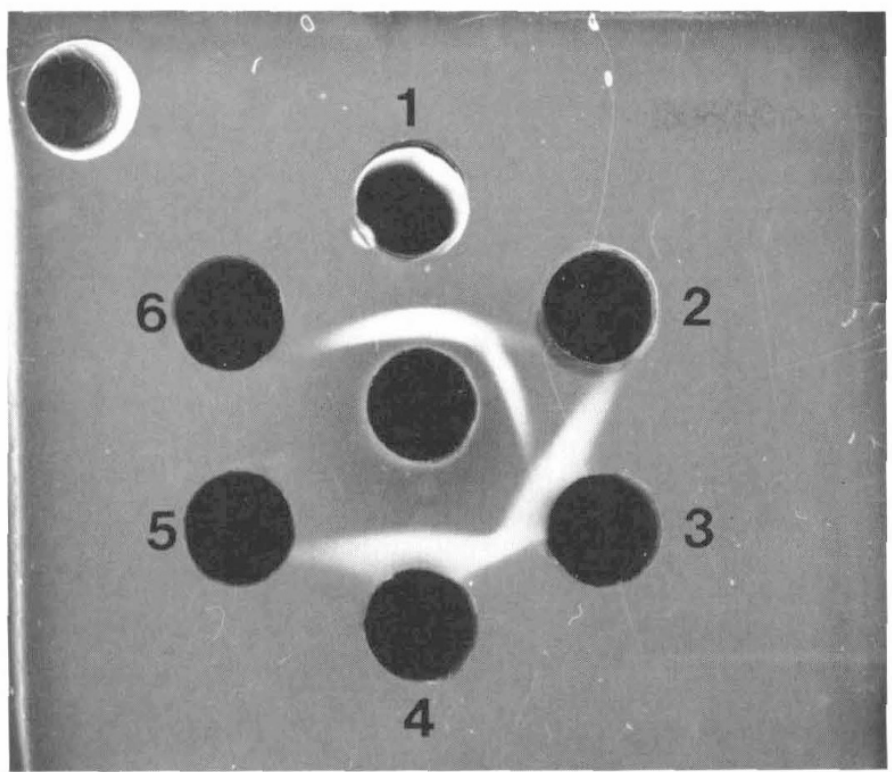

Fig. 1. Ouchterlony immunodiffusion. The center well contained purified antihuman lactoferrin antibodies from Dako. The antigens evaluated were: porcine lactoferrin purified by the single-stranded DNA affinity method (well l), bovine lactoferrin from Sigma (well 2), human lactoferrin purified by the single-stranded DNA affinity method (well 3), human lactoferrin obtained from Jackson ImmunoResearch (well 4), human transferrin from Sigma (well 5), and a buffer control (well 6)

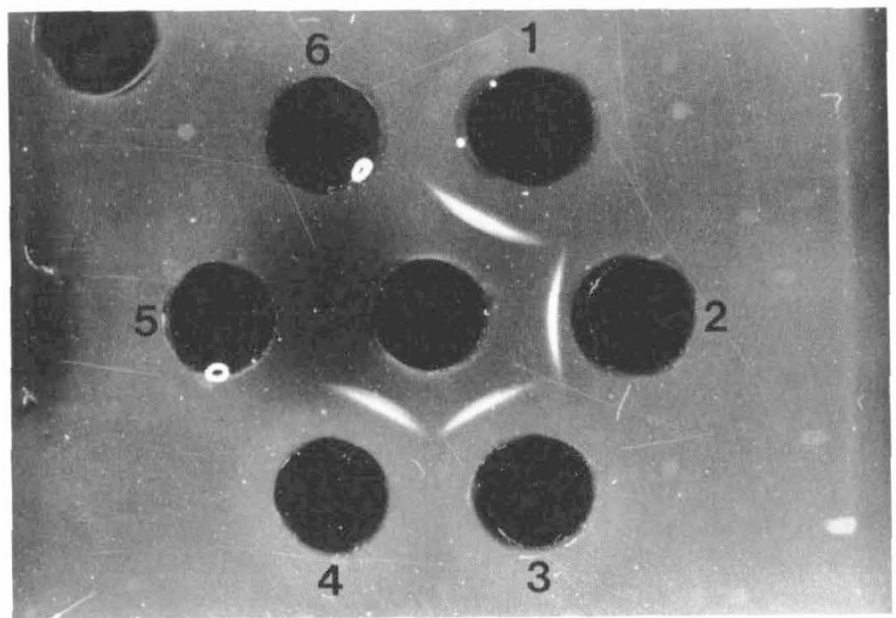

Fig. 2. Ouchterlony immunodiffusion. The center well contained purified antibovine lactoferrin antibodies from Bethyl. The antigens evaluated were: porcine lactoferrin purified by the single-stranded DNA affinity method ( well $l$ ), bovine lactoferrin from Sigma (well 2), human lactoferrin purified by the single-stranded DNA affinity method (well 3), human lactoferrin obtained from Jackson ImmunoResearch (well 4), human transferrin from Sigma (well 5), and a buffer control (well 6).

antisera evaluated, serial dilutions of the nonhomologous antigens allowed for identification of lactoferrin concentrations where only the homologous reactions developed visible precipitin lines. Each of the antihuman lactoferrin antibodies reacted with porcine lactoferrin to a greater extent than with bovine lactoferrin. This finding was evident when the antigens were presented at equal concentrations (Fig. 1). In contrast, parallel evaluations of human transferrin at an equivalent concentration revealed no evidence of immunoprecipitation using antibodies directed against lactoferrin from any of the species evaluated.

Evidence of lactoferrin antibody cross-reactivities obtained by Ouchterlony immunodiffusion was confirmed and extended by immuno dot blot analyses. The more sensitive immuno dot blotting technique showed stronger evidence for the presence of

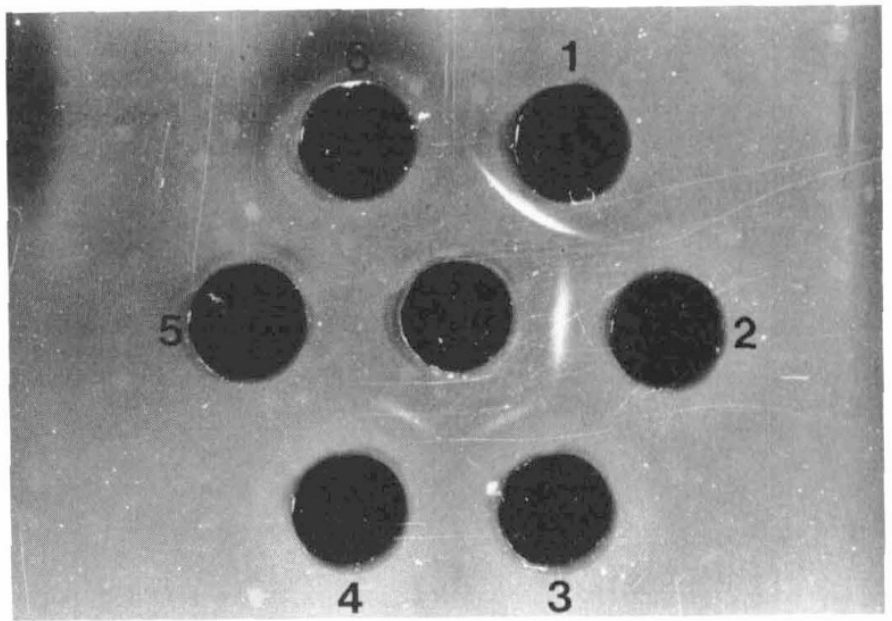

Fig. 3. Ouchterlony immunodiffusion. The center well contained purified antiporcine lactoferrin antibodies from Bethyl. The antigens evaluated were: porcine lactoferrin purified by the single-stranded DNA affinity method (well $l$ ), bovine lactoferrin from Sigma (well 2), human lactoferrin purified by the single-stranded DNA affinity method (well 3), human lactoferrin obtained from Jackson ImmunoResearch (well 4). human transferrin from Sigma (well 5), and a buffer control (well 6).

shared antigenic determinants than was seen by Ouchterlony immunodiffusion. Figure 4 demonstrates the positive reaction of human lactoferrin, bovine lactoferrin, and porcine lactoferrin when probed by purified antibodies directed against human lactoferrin, bovine lactoferrin, and porcine lactoferrin. Positive reactions were observed for each combination of antigen and antibody, regardless of source. Results similar to those shown in Figure 4 were obtained with unfractionated, diluted antisera $(1: 10)$, probably as a result of the increased sensitivity of this technique relative to Ouchterlony immunodiffusion. No significant reactions were observed with human transferrin as a control protein.

Because lactoferrin is predisposed to association with other proteins, including $\operatorname{Ig}(22)$, it was important to determine whether nonspecific interactions between the different lactoferrins and the various immunologic reagents might give rise to false positive results. This was a particular concern because of the sensitivity of the immuno dot blot technique. Blots with both positive and negative controls were performed routinely (Fig. 4). Developed blots of the various lactoferrin proteins alone (no antibodies), or lactoferrin with secondary antibody only (row $F$; no primary antibody) were negative. Similarly, blots with secondary antibodies alone (row $A$; no primary antibody or lactoferrin) or primary and secondary antibodies alone (row $G$; no lactoferrin) and buffers alone were negative. Slightly elevated backgrounds were occasionally observed, depending on the membrane type and the individual protein chosen to block nonspecific adsorption phenomena. None of the positive reactions obtained during the course of these investigations could be accounted for by nonspecific interactions.

The degree of lactoferrin antibody cross-reactivity was also evaluated for each species of lactoferrin by SDS-PAGE and immunoblotting. The immunoblotting profiles shown in Figure 5 confirm the evidence for cross-reactivity obtained by Ouchterlony immunodiffusion and immuno dot blotting under nondenaturing conditions. Under denaturing (but nonreducing) conditions, antihuman lactoferrin antibodies cross-reacted with porcine lactoferrin to a greater extent than with bovine lactoferrin. Antibovine lactoferrin antibodies, however, cross-reacted more strongly with porcine lactoferrin than with human lactoferrin. Antibodies directed against porcine lactoferrin showed the same degree of cross-reactivity toward human and bovine lactoferrins. Transferrin was not recognized by any of the three antilactoferrin antibodies under these conditions. 
JhLF hLF pLF MbLF ShTF

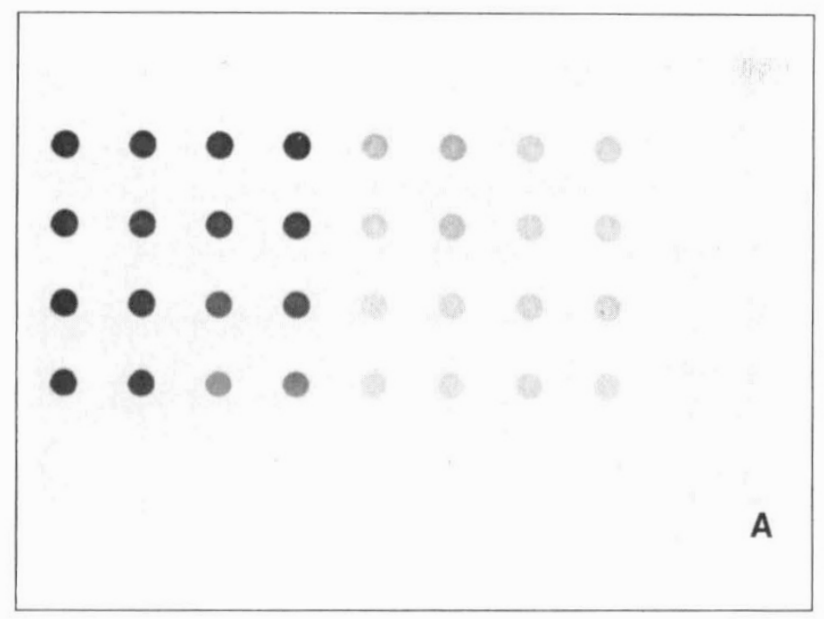

JhLF hLF pLF MbLF ShTF

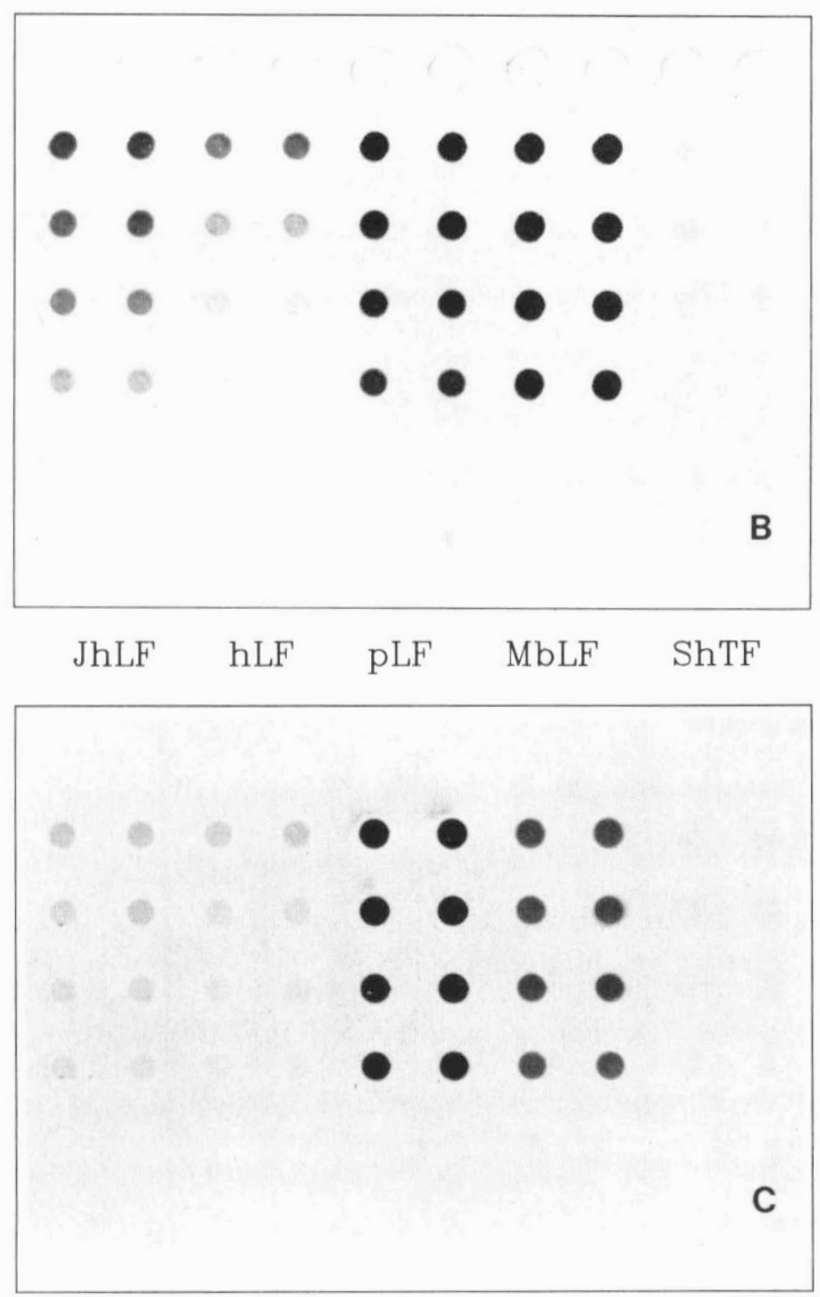

Fig. 4. Immuno dot blots. Purified antigens are as indicated: human ctoferrin. $h L F$ and $J h L F$ (Jackson ImmunoResearch); bovine lactofern. $M h L F$ (Morinaga); porcine lactoferrin, $p L F$; human serum transfern, ShTF (Sigma). Antigens without a specified source were those repared by us as described in Methods. Each evaluation shown was erformed in duplicate. Rows $B-E$ represent serial dilutions (3.75-0.24 g) of the specified antigens. Control blots with secondary antibody only (11 4), antigen $(3.75 \mu \mathrm{g})$ and secondary antibody only (row $F$ ), and imary and secondary antibody only (row $G$ ) were indistinguishable om the unreacted nitrocellulose. Panel A was blotted with purified tihuman lactoferrin antibodies (Dako). Panel B was blotted with Irified antibovine lactoferrin antibodies (Bethyl). Panel $C$ was blotted th purified antiporcine lactoferrin antibodies (Bethyl). The results own are representative of $>20$ similar comparisons.

\section{A}

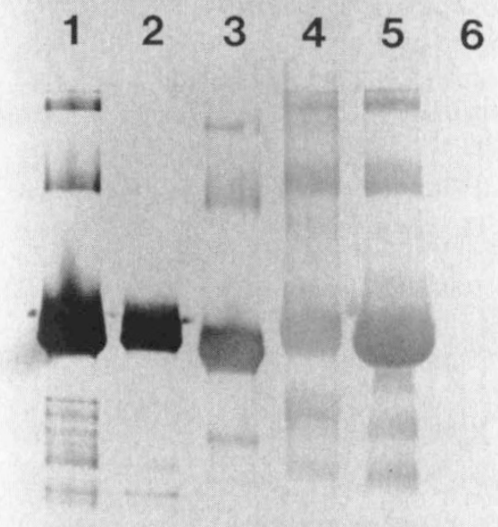

B

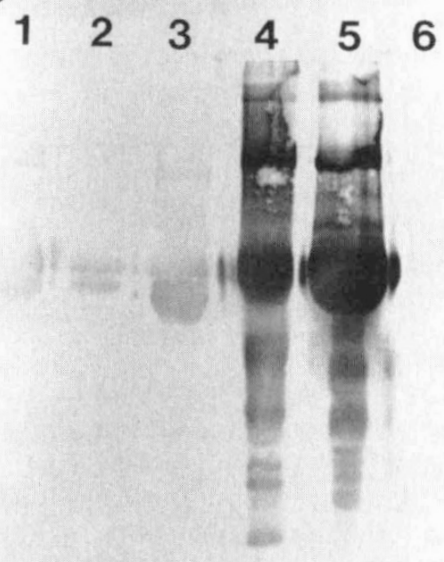

C

Fig. 5. Western transfer and immunoblots of lactoferrins analyzed by SDS-PAGE. Sample denaturation was performed under nonreducing conditions. Panel A was blotted with purified antihuman lactoferrin antibodies (Dako). Lanes indicated are: I, human lactoferrin (Jackson ImmunoResearch), 2, human lactoferrin (purified by single-stranded DNA), 3, porcine lactoferrin (purified by single-stranded DNA), 4, bovine lactoferrin (purified by single-stranded DNA), 5, bovine lactoferrin (Sigma), and 6, human transferrin (Sigma). Panel B was blotted with purified antibovine lactoferrin antibodies (Bethyl). Lanes indicated are: 1. human lactoferrin (Jackson), 2, human lactoferrin (single-stranded DNA), 3, porcine lactoferrin (single-stranded DNA), 4, bovine lactoferrin (single-stranded DNA), 5, bovine lactoferrin (Sigma), and 6, human transferrin (Sigma). Panel $C$ was blotted with purified antiporcine lactoferrin antibodies (Bethyl). Lanes indicated are: 1 , human lactoferrin (Jackson), 2, human lactoferrin (single-stranded DNA), 3, porcine lactoferrin (single-stranded DNA), 4, bovine lactoferrins (single-stranded DNA), 5, bovine lactoferrin (Sigma), and 6, human transferrin (Sigma).

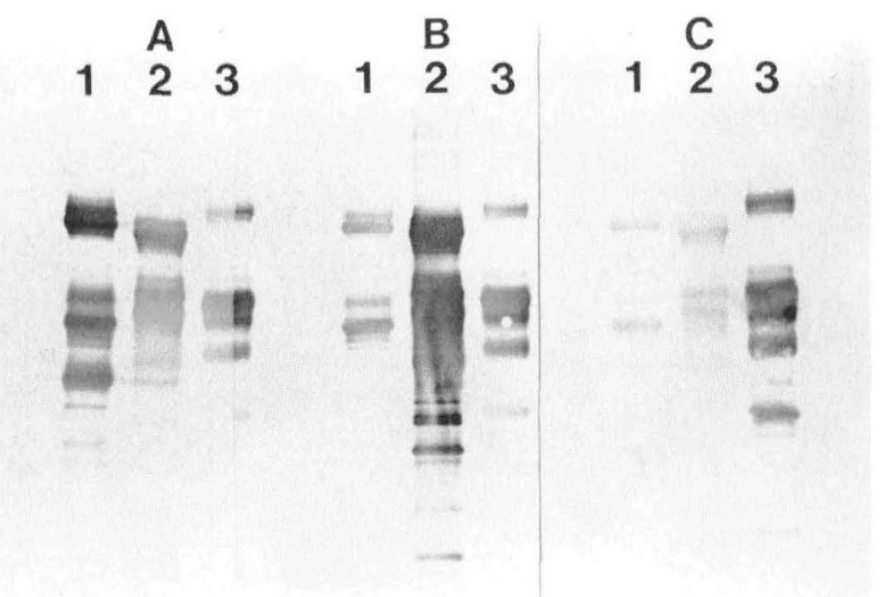

Fig. 6. SDS-PAGE, Western transfer and immunoblots of human, porcine, and bovine lactoferrins after trypsin digestion. Sample denaturation was performed under nonreducing conditions. Panel $A$ was blotted with purified antihuman lactoferrin antibodies (Dako). Lanes indicated are: $I$, digested human lactoferrin (Jackson ImmunoResearch); 2, digested porcine lactoferrin (purified by affinity chromatography on singlestranded DNA): and 3. digested bovine lactoferrin (Morinaga). Note: the right-hand portion of lane $3 A$ was cut and blotted with antiporcine lactoferrin antibodies. Panel $B$ was blotted with purified antiporcine lactoferrin antibodies (Bethyl). Lanes indicated are: 1, digested human lactoferrin (Jackson ImmunoResearch), 2, digested porcine lactoferrin (purified by affinity chromatography on single-stranded DNA), and 3, digested bovine lactoferrin (Morinaga). Panel $C$ was blotted with purified antibovine lactoferrin antibodies (Bethyl). Lanes indicated are: 1 , digested human lactoferrin (Jackson ImmunoResearch); 2, digested porcine lactoferrin (purified by affinity chromatography on single-stranded DNA); and 3, digested bovine lactoferrin (Morinaga).

Western blots of SDS-polyacrylamide gels have been used with increasing frequency to evaluate the metabolic fate of ingested human and bovine lactoferrins. Thus, the trypsin digestion products from human, porcine, and bovine lactoferrins were evaluated by SDS-PAGE and Western immunoblotting. This method also enabled the identification of specific regions (peptides) of common structure and antigenicity. The results shown in Figure 6 reveal that the individual trypsin digestion products (i.e. peptides) from each given species of lactoferrin varied distinctly in antigenicity. Peptides with and without shared antigenic determinants were observed regardless of whether the trypsin digestion products were denatured in the presence or absence of reducing reagent. Although the lactoferrins varied in their tryptic digestion patterns (under both reducing and nonreducing conditions), common digest products could be identified that were responsible for shared as well as unique antigenicity.

\section{DISCUSSION}

The protein now referred to as lactoferrin was first discovered in 1939 and partially purified from bovine milk by Sorensen and Sorensen (23). It has since been identified in the colostrum and milk of several other species $(1,5,7-10,13,14,24,25)$. Lactoferrin is also stored in neutrophil granules and is a major protein component of various mucosal secretions (1). In addition to iron binding, a number of other biologically important functions have been ascribed to lactoferrin (1). Its primary function and use are uncertain and may vary on the basis of location, metal ion availability, and posttranslational modification.

Immunologic reagents are used extensively to monitor the presence and concentrations of lactoferrin in biologic fluids. In the field of infant nutrition and preterm infant care, the biology of lactoferrin has been a primary focus of attention (16, 26-32). Within this context, it is particularly important to establish the degree to which bovine and human lactoferrins do or do not share immunologic determinants, because the differential function and metabolic fate of ingested lactoferrins is unknown. Several investigations have been directed toward understanding the relative nutritional and immunologic contributions (i.e. use) of lactoferrin. Preterm infants fed human milk have been reported to have increased levels of both fecal and urinary outputs of lactoferrin (26-28). Whether the urinary lactoferrin is exclusively of dietary origin is not yet known (16). If infants were fed cow milk formula along with human milk, or infant formula with added bovine lactoferrin, problems with the separate immunologic detection of human and/or bovine lactoferrin (or their fragments) may have been or may be underestimated. Questions certainly arise in regard to the immunologic detection and quantitation of human lactoferrin in clinical specimens obtained from infants fed cow milk formulas alone or formulas based on cow milk that has been fortified with human milk fractions. Similar complications may also be encountered during the experimental evaluation of transgenic cows and pigs designed to produce human lactoferrin. These concerns are particularly valid when sensitive methods of detection are used.

Despite previous reports arguing the absence of cross-reactivity between lactoferrins of different species, our data have demonstrated unequivocally that cross-reactivity occurs between human, porcine, and bovine lactoferrin. The degree of cross-reactivity varies between species. The ability to detect cross-reactivity, if desired, varies with antibody titer, purity, and method of detection. The degree of antibody cross-reactivity will have to be determined separately for each antiserum (or MAb), sample type, and method of detection (28). Increased caution is particularly necessary in the interpretation of either qualitative or quantitative immunologic methods of evaluating human and bovine lactoferrin digestion products.

The next stage of this investigation will be to determine the precise location of shared antigenic determinants on the surface of the different lactoferrins. Speculation is inappropriate at this time regarding the biologic significance or possible functional relationships (e.g. receptor-binding or metal-binding domains) of lactoferrin structures with preserved antigenic determinants.

\section{REFERENCES}

1. Brock JH 1985 Transferrins. In: Harrison P(ed) Metalloproteins. Part 2: Metal Proteins with Non-redox Roles. Topics in Molecular and Structural Biology Verlag Chemie, Basel, pp 183-262

2. Anderson BF. Baker HM. Dodson EJ. Norris GE, Rumball SV, Waters JM Baker EN 1987 Structure of human lactoferrin at 3.2-A resolution. Proc Natl Acad Sci USA 84:1769-1773

3. Ainscough EW, Brodie AM, Plowman JE, Bloor SJ, Loehr JS, Loehr TM 1980 Studies on human lactoferrin by electronparamagnetic resonance. fluorescence, and resonance raman spectroscopy. Biochemistry 19:4072-4079

4. Metz-Boutigue MH, Jolles J, Mazurier J. Schoentgen F, Legrand D. Spik G, Montreuil J. Jolles P 1984 Human lactotransferrin: amino acid sequence and structural comparisons with other transferrins. Eur J Biochem 145:659676

5. Hutchens TW, Magnuson JS. Yip TT 1989 Rapid purification of porcine colostral whey lactoferrin by affinity chromatography on single-stranded 
DNA-agarose. Characterization, amino acid composition and $\mathrm{N}$-terminal amino acid sequence. Biochim Biophys Acta 999:323-329

6. Wang C-S, Chan W-Y. Kloer UH 1984 Comparative studies on the chemical and immunochemical properties of human milk, human pancreatic juice and bovine milk lactoferrin. Comp Biochem Physiol [B] 78:575-580

7. Jolles J. Donda A. Amiguet P. Jolles P 1984 Mare lactotransferrin: purification. analysis and N-terminal sequence determination. FEBS Lett 176:185-188

8. Davidson LA. Lonnerdal B 1986 Isolation and characterization of rhesus monkey milk lactoferrin. Pediatr Res 20:197-201

9. Pentecost BT. Teng CT 1987 Lactoferrin is the major estrogen inducible protein of mouse uterine secretions. J Biol Chem 262:10134-10139

0. Kokriakov VN, Aleshina GM. Slepenkov SV. Iakovleva MF, Pigarevskii VE 1988 O stepeni strukturnoi gomologii laktoferrinov moloka i neitrofil'nvkh granulotsitov. Biokhimiia 53:1837-1843

1. Norris GE, Anderson BF. Baker EN. Baker HM. Gartner AL, Ward J, Rumball SV 1986 Preliminary crystallographic studies on bovine lactoferrin. J Mol Biol 191:143-145

12. Vigh R, Cser L, Kilar F, Simon I 1989 Different segmental flexibility of human serum transferrin and lactoferrin. Arch Biochem Biophys 275:181-184

13. Masson PL. Heremans JF 1971 Lactoferrin in milk from different species. Comp Biochem Physiol [B] 39:119-129

14. Rotova GM, Kokriakov VN. Slepenkov SV. Mazing YA. Pigarevskii VE 1985 Poluchenie i nekotorve fiziko-khimicheskie svoistva laktoferrina i neitrofilov svini i. Biokhimiia 50:1448-1452

15. Hutchens TW. Magnuson JS, Yip TT 1989 Interaction of human lactoferrin with DNA: One-step purification by affinity chromatography on singlestranded DNA-agarose. Pediatr Res 26:618-622

6. Hutchens TW, Henry JF. Yip TT 1989 Purification of intact lactoferrin found in the urine of human milk-fed preterm infants. Clin Chem 35:1928-1933

7. Hutchens TW. Porath J 1986 Thiophilic adsorption of immunoglobulinsanalysis of conditions optimal for selective immobilization and purification. Anal Biochem 159:217-226

18. Porath J, Hutchens TW 1987 Thiophilic adsorption: a new kind of molecular interaction. Int J Quant Chem 14:297-315
19. Hutchens TW. Porath J 1987 Thiophilic adsorption. A comparison of model protein behavior. Biochemistry 26:7199-7204

20. Levy HB, Sober HA 1960 A simple chromatographic method for preparation of gamma globulin. Proc Soc Exp Biol Med 103:250-252

21. Ouchterlony O 1967 Immunodiffusion and immunoelectrophoresis. In: Weir DM (ed) Handbook of Experimental Immunology. FA Davis Co, Philadelphia, pp 655-706

22. Boesman-Finkelstein M. Finklestein RA 1982 Sequential purification of lactoferrin, lysozyme and secretory immunoglobulin A from human milk. FEBS Lett 144:1-5

23. Sorensen M, Sorensen SPL 1939 Comptes Rendus Des Travaux Du Laboratoire Carlsberg. Série Chimique 23:55

24. Kinkade Jr JM, Miller III WWK, Segars FM 1976 Isolation and characterization of murine lactoferrin. Biochim Biophys Acta 446:407-418

25. Roberts TK, Boursnell JC 1975 The isolation and characterization of lactoferrin from sow milk and boar seminal plasma. J Reprod Fertil 42:579-582

26. Schanler RJ, Goldblum RM, Garza C, Goldman AS 1986 Enhanced feca excretion of selected immune factors in very low birth weight infants fed fortified human milk. Pediatr Res 20:711-715

27. Prentice A, Ewing G, Roberts SB, Lucas A, MacCarthy A, Jarjou LM, White head RG 1987 The nutritional role of breast milk IgA and lactoferrin. Act. Paediatr Scand 76:592-598

28. Goldblum RM, Schanler RJ, Garza C, Goldman AS 1989 Human milk feeding enhances the urinary excretion of immunologic factors in low birth weight infants. Pediatr Res 25:184-188

29. Spik G. Brunet B, Mazurier-Dehaine C. Fontaine G, Montreuil J 1982 Characterization and properties of the human and bovine lactotransferrins ex tracted from the faeces of newborn infants. Acta Pediatr Scand 71:979-985

30. Prentice A, MacCarthy A, Stirling DM, Vasquez-Velasquez L, Ceesay SM 1989 Breast-milk $\operatorname{IgA}$ and lactoferrin survival in the gastrointestinal tracta study in rural Gambian children. Acta Paediatr Scand 78:505-512

31. Scott PH 1989 Enzyme immunoassay of lactoferrin in newborn term infants: reference values and influence of diet. Ann Clin Biochem 26:407-41 I

32. Scott PH 1989 Plasma lactoferrin levels in newborn preterm infants: effect of infection. Ann Clin Biochem 26:412-415 